\title{
Shared Field, Divided Field
}

\section{Expectations of an Anthropological Couple in Southeast Asia}

\author{
Felix Girke
}

\section{“TWO ANTHROPOLOGISTS GO INTO ONE FIELD...”}

This sounds like the beginning of a worn joke, but as early as 30 years ago, Ilva Ariëns and Ruud Strijp declared that anthropology was "a meeting-place where amorous relationships have come into existence" (just as in any professional environment really) while the interplay of the "emotional and professional dimensions of these relationships" (1989: 5) had hardly ever been discussed. This complaint still stands today. Anthropology has taken remarkable steps in terms of personal and disciplinary introspection, reflection on methods and theory, ethnographic writing and even institutional aspects such as gender balance; however, the question of how partners and families actually live their anthropological lives is still shrouded in the much decried mysticism that for so long has haunted fieldwork and the way it is taught. While by no means resolved, the difficulties of fieldwork with children have at least (and at last) become a recognized element of disciplinary discussions ${ }^{2}$ and are at times even acknowledged by funding

1 I thank Corinna Di Stefano for her comments on this chapter, as well as the editors and the participants at the workshop in Cologne from which this volume sprang. My fieldwork in Myanmar was supported by ZIRS (the Center for Interdisciplinary Area Studies) at the University of Halle-Wittenberg, the University of Konstanz and especially the DFG (German Research Foundation), to whom I am duly grateful.

2 E.g., the classic publications by Joan Cassell (1987) and Barbara Butler and Diane Michalski Turner (1987), the recent volume on "Accompanied fieldwork" by Candice Cornet and Tami Blumenfield (2016), and several contributions to this volume. Worth mentioning is the film Sweet Sorghum by Rosie Strecker and Ivo Strecker, reflecting on the years of her childhood spent in her parents' field in southern Ethiopia (1995). In 
agencies. ${ }^{3}$ The specific constellation of going into and being in the field with (and as) a partner has received considerably less attention. This is remarkable. Ilva Ariëns and Ruud Strijp stated quite early that anthropologists "first had to write on their children" before turning to their "own personal and scientific relationships" (ibid: 5) 4 $^{4}$ I will touch on some of the reasons why partnership might still be an even more sensitive topic than one's own children throughout this chapter.

Below, I discuss some well-known anthropologist couples; but despite these individuals' relative renown, decades of reflection on fieldwork and positionality have meandered around the uncomfortable problems that emerge from the constellation of two legally or romantically partnered academics who go on fieldwork together, whether with a child or without one. To ground my motivation for pursuing this problematic: my partner (who is also an academic anthropologist) and I went on fieldwork to urban Myanmar together with our son. Looking back on that time, everything considered, we found it more challenging to meet the professional (and strategic) difficulties of being on fieldwork at the same time as partners than to be parents in the field, hence my emphasis on the former. One thread running through my discussion is that of expectations - expectations of the field and of "being there", expectations of how we would have to negotiate out positionality within anthropology, and expectations regarding our family and partnership during fieldwork. "Expectations of", of course, can be read both ways: our expectations, and expectations others had of us; as well as, to conjoin the two, what we expected others to expect of us. Much of what we did and how we positioned ourselves is a result of attending to such expectations, many of which are probably widespread through the discipline, while others might be more idiosyncratic.

My partner and I both pursued separate fieldwork projects throughout, but through a mix of persuasion, luck and stubbornness managed to arrange our duties

recent years, the online portal AllegraLab has hosted short pieces on "\#fieldwork with children" (e.g., Halme-Tuomisaari 2017; McGranahan 2015; Toivanen 2015); other blogs offer similar items.

3 A three-year phase of my research has been funded by the German Research Foundation (DFG). When I received the confirmation letter, it included some of the reviewers' comments. One stated that while they did not know for sure whether the DFG would pay for the costs of bringing a child on field research, they certainly endorsed my asking for such funds.

4 And even though they and their contributors wrote about this topic, it helped little. Their thematic edited issue of FOCAAL on "anthropological couples" (with contributions by Micheline and Pierre Centlivres, Nancy and Richard Tapper, Elizabeth and Robert Fernea, Carolyn Fluehr-Lobban and Richard Lobban) is hardly ever cited in anthropological texts on fieldwork. 
at our sites of employment in Germany, our funding schemes, and our family arrangements to enable us to avoid having to separate our family for the periods of this postdoctoral fieldwork. It seemed fundamentally undesirable to split the family for fieldwork, so to manage our affairs in this way was a test of our joint determination. In that sense, our decision constituted an active attempt to conjoin family life and fieldwork, rather than a reactive one of merely trying to avoid the loneliness of the ethnographer (cf. Ariëns and Strijp 1989: 7).

This chapter, then, starts from disciplinary history and, by way of our experience of two people, partners, who are "in the field" together (without being all too confessional), will go on to problematize the subtle difference between "in the field" and "on fieldwork". Throughout, I will seek to address expectations of fieldworkers regarding social integration, immersion, scope and other aspects of the research situation, abstractly as well as autobiographically. The specificity of going into the field as symmetrical partners (with both pursuing research projects) comes out when contrasted to two other constellations.

First, it is not uncommon today to incidentally encounter other anthropologists during fieldwork. Such encounters with colleagues can be fraught with unspoken tension: We (still?) speak of "our fields", and even if we do try to not project ownership claims outward when we do so, the pronoun is hardly controllable. "Being there" and "having been there", that is, much of our ethnographic authority depends to a degree on exclusivity, on privileged access to another lifeworld or social environment. The other researcher, not another Other but another "I", carries with them some threat or at least challenge to that exclusivity in their mere presence, let alone if we find out that we are, in fact, pursuing similar research questions in the same place - or that they are further along than we are, know the language better, seem better integrated, come from a more prestigious institution, or are simply better funded: all such observations might serve to undermine our confidence and increase the stress we operate under. ${ }^{5}$ As long as our knowledge and ethnographic authority rests to a degree on individual and exclusive achievement, the other "I" is a potential challenger. This sort of competitive tension was something that we ruled out ever allowing to emerge.

5 However, this is an empirical question: meeting another "I" in the field might just as well offer a refuge, a "time out" from the flow of everyday life, a chance to exchange ideas; and in fact, this positive synergy and its possible and factual merits are acknowledged in the increasing attention that fieldwork in teams is (again) receiving. See Martin Thomas and Amanda Harris (2018) on the older "eclipsed" tradition, and Judith Schlehe (2013) and Mathias Heybrock (2018) on a current practical approach from the University of Freiburg to teaching anthropological teamwork in the field. 
Second, it is another familiar permutation that an anthropologist does not go into the field by themselves, but with a partner who is not an anthropologist (like Matthew Engelke's "untrained wives" [2001: 126]). Beyond the well-worn acknowledgment sections, this sort of fieldwork is tacitly understood to occur but is rarely discussed. But there, the non-academic spouses and children are both thanked for enduring the necessary time spent in the field, as well as the subsequent writing-up process, during which the scholar unfortunately had to absent themselves from domestic duties. This is an ambivalent positioning: acknowledgment sections are notoriously sites not only of introspection and displays of genuine gratitude, but also of bare-faced "careering" (Ben-Ari 1987). ${ }^{6}$ But it was clear that in our case we could not allow any such asymmetry to intrude: neither of us was accompanying the other (or even following, as I will explain in more detail below), and for our arrangement to succeed, both our projects needed to have equal priority in planning and decision-making.

Thinking through the various configurations of not going into the field alone is not intended to set up a hierarchy, but rather to highlight specific expectations anthropologists might face, and how a certain kind of partnership will shape how one faces questions of symmetry and equity, as researchers and - as in our case as parents.

\section{FIELD RESEARCH IN A SOUTHEAST ASIAN METROPOLIS}

In their introduction to their thematic FOCAAL issue, Ilva Ariëns and Ruud Strijp report that they asked 14 "anthropological couples" for a contribution, but only four affirmative replies were returned - intriguingly, all based on fieldwork in the Middle East, an area, as the authors emphasize, of "more or less strict sexual segregation" (1989: 6). This precondition, it is suggested, had the effect that "the

6 Anecdotally, I recall that during my student days in the 1990s, more senior figures in the discipline were discussed in terms of whether they had found a partner "aus dem Fach oder aus dem Feld" (from the discipline or from the field-site), and both constellations were amply represented even in our still limited social landscape. The underlying insinuation was surely that the anthropologist's life was such (extreme? particular? demanding?) that these two options were preferable to partnering with someone who was neither. I cannot speak for my peers at the time, but it is well imaginable that certain expectations were imprinted on us even then. "You can pick whoever you like, but," so the short phrase seemed to hint, "don't be surprised if it doesn't work out." 
limitations of fieldwork experiences in these societies" (ibid: 6) were particularly evident. ${ }^{7}$ But this assumption implies that both partners in the field pursued some holistic vision, and that they apparently worked in shared fields, and not a divided field.

What sets my personal experience of doing fieldwork as one half of an anthropological couple apart from most of the examples discussed above is largely encapsulated in this chapter's title: my partner and I shared a field, and yet the field was divided. And it was not simply divided along gender lines, the set-up that Ilva Ariëns and Ruud Strijp suggest the contributors to their volume followed so productively (and sustainably). The tension between "shared" and "divided" works more subtly in German - both are easily rendered as geteilt, and this, too, was a very conscious decision quite early in our planning stages. Our very first ideas revolved around research on moral tourism under the condition of a travel boycott since the late 1990s (intended as an empirical extension of Jim Butcher [2003] and Andrea Valentin [2009]), as at the time it seemed that this focus might be innocuous enough to allow for relatively unfettered access to the "field". But this idea was soon confronted with political changes in Myanmar: as sanctions were dropped, our idea of studying how tourists operated to make their stay in Myanmar morally tenable lost its most interesting element. We never again returned to the idea to jointly work on a singular research question. Also, the time in which anthropologists simply went into a field and studied what they found there seemed to be over, for good or bad, so we each came to conceptualize an individual research project. Both had in common that much of the empirical data that we were after was to be found in Yangon, the former capital of Myanmar, with a focus on the colonial downtown, the townships of the central business district. We felt that our research projects needed to be clearly and cleanly delineated and separable at any given point: we were both seeking to produce research that added to our personal academic profiles, and we needed to avoid having our research appear as an entangled or conflated conglomerate that we had jointly produced. While we have already published together, and will at times continue to do so, we understood fieldwork strategically as something that must distinguish the individual researcher. These considerations and concerns seemed more pressing before and during fieldwork than any practical matters that had to do with bringing our child into the field, or how the factor of having a child in the field would affect our work. The care that we took to keep our professional profiles apart also began

7 The subsequent suggestion that "it appears that the contributions of a partner of the other sex [in the context of fieldwork in the Middle East] are valued so much, that the authors have felt the necessity to reflect on their cooperation" (Ariëns and Strijp 1989: 6) seems a little over-enthusiastic. 
much earlier, with our decision not to use a common last name in professional contexts. Margaret Mead (1970) herself had choice words about those researchers who went into the field as "anthropological couples" but did not even attempt to balance the career opportunities of both partners. She emphasized that female anthropologists took on "the combined role of secretary and technical assistant, at rates cheaper than such functions command in the market place" (ibid: 326). ${ }^{8}$ But Ilva Ariëns and Ruud Strijp highlighted that while for a long time "the professional advantages nearly always accrued to the male partner" (1989: 10), this was changing - that "not only the number of female anthropologists has increased, but also that they pay more attention to their own scientific ambitions and no longer give priority to the education of their children or to their husband's career" (ibid: 6). ${ }^{9}$

I do not recall us very explicitly discussing the division of labor in the field, either beforehand or during our research periods. It was understood nevertheless that we strove for radical egalitarianism - rather than accountable balance - in how we each took on the various tasks that arose in managing both the family and our respective fieldwork. When one of us needed to be somewhere, saying "It would be great if I went there now" meant that the other took care of the household and the family without asking questions or demanding any further justifications. It was clear for both of our projects that sudden developments (and the "anthropology by appointment" so typical of urban research) would require reactivity to unplanned occurrences, and it was paramount for both of us to prevent the sense of "the partner/the child is preventing me from researching" ever arising, even if sometimes one person had to let go of some less firmly held plans in order to accommodate the other. But we never kept score.

8 Cited in Ilva Ariëns and Ruud Strijp (1989: 8). See also Ernest Gellner as cited in Eyal Ben-Ari (1987: 77) for a proactive take on this very suggestion.

9 Well before that time, Margaret Mead herself is of course an exceptional case: she was successively married to three anthropologists, and was in the field with two of them, an arrangement that has stimulated the anthropological and literary imagination. While fictional, Lily King's recent book Euphoria (2014), which retells the Papuan ménage a trois between a faux-Fortune, a mostly-Mead and a nearly-Bateson, very plausibly conjures up the tensions and (literarily exaggerated) dangers, but also the creative potential of shared fieldwork. 


\section{ANTHROPOLOGICAL COUPLES}

Even as we sought to chart our own course through fieldwork, as an anthropological "professional couple", we never existed in a historical vacuum. Some of the better known "anthropological couples" even hold a special place in our disciplinary imaginary, especially when they are known to have done fieldwork together. Some of these are even referred to by their shared last name. I have at times heard people speak about "the Comaroffs", about "the Benda-Beckmanns", about "the Turners", "the Geertzes", "the Bohannans", and (less reliably) about "the Goodies", the "Hugh-Joneses" or "the Rosaldos". ${ }^{10}$ There are many more who do not have a conveniently shared last name, in Germany most prominently Ivo Strecker and Jean Lydall, and globally the aforementioned Margaret Mead and Gregory Bateson, and Fredrik Barth and Unni Wikan.

While Ivo Strecker and Jean Lydall, with their Work Journal (1979), have offered edited-yet-candid insights into the dynamics of their shared fieldwork, for many of the other cases we are reliant on sources such as retrospective interviews and marginal footnotes for glimpses of how those couples came to share a fieldwork stay and how that unfolded. Some examples of this kind of writing must suffice. The citations below point to very different sorts of relationships and circumstances. Jointly, they indicate that there is no established genre or medium for this specific biographical aspect of anthropological lives.

In an interview intended to serve as part of disciplinary history, Stephen HughJones explained the "we" of his narrative to Alan MacFarlane, and how "we" entered the field:

"Should explain the 'we'; Christine had started doing sociology at the L.S.E. with a bias towards anthropology and very quickly transferred to anthropology; ... she was a year behind me although older than me; we had married in my second year as an undergraduate and we knew we wanted to do fieldwork together; there was some debate on where we should go as she was quite keen on New Guinea and I was absolutely certain I was going to Amazonia; after graduation I spent a year in King's supervising and reading as much as I could about Amazonia while Christine finished; she graduated in July and by the end of August we were in the field - so much for pre-fieldwork training that they have to do now..." (2007: 54:26:10)

10 There are more, still (Godfrey and Monica Wilson, Pat and Lionel Caplan, Barbara and Dennis Tedlock), but many are only familiar to regional or thematic specialists. 
Others were similarly or even more circumspect. Keith Hart (2015) recounts Jack Goody's early life, including how his first marriage "did not survive the prolonged absences" (due to fieldwork in Northwest Ghana), and sums up the emergence of an anthropological couple in two sentences: "He married Esther Newcomb, his American doctoral student, in this period and they had two daughters. Jack and Esther Goody became a team in the following decades, frequently spending time in Ghana and publishing together and separately."

The Comaroffs provide more intriguing details in a shared interview, which hints at the influence of other couples, and their engaged stance-taking vis-à-vis what they perceived to be institutional constraints on their partnership:

John: "Jean and I met in anthropology where Monica Wilson took us under her wing. She and her husband had been an anthropological couple; she had done a kind of historical anthropology and was coeditor of The Oxford History of South Africa. We went on to write historical anthropology and Jean worked on ritual, so there was a very strong genealogical link with her." (Appelbaum 2011: 15:14:03)

Jean: "There were nepotism clauses in force in British Universities at that stage; husbands and wives could not be in the same department." (ibid: 16:25:00)

John: "Jean has a wonderful line which is absolutely true. Social anthropology was deeply gendered when we were at the LSE, so she 'got' religion and I 'got' politics; the LSE didn't entertain any possibility of us doing a $\mathrm{PhD}$ together. The model of the individual author really did apply; it was no different here [in the USA]. Basically, we started to write together as a way of arguing with that tradition." (ibid: 34:08:12)

From Marilyn Strathern (2009), we can glean little more than that some domestic difficulties occurred while in the field (cf. Strathern and Czegedly 1992/93: 2):

"Managing relationships was fraught; for a while I was by myself because we thought we had different PhDs to get from this work, and Andrew went off in one direction and I in another; I had a house built much closer to Hagen town at a place called Kelua and I was there by myself for two or three months, and quite lonely; the tension manifested itself in indigestion; after the evening meal I would withdraw to have a bit of time to myself, but it would invariably end with me lying on my camp bed on my stomach trying to get rid of indigestion." 11

11 This is an exceptionally asymmetrical case, as most people I asked were not even aware that Marilyn and Andrew Strathern had been partners, as her fame so overshadows his. Regarding the domestic difficulties mentioned, while I have no indication of whether the divorces among anthropological couples (e.g. the Bohannans, the Stratherns, the Geertzs, Margaret Mead and her various husbands) are directly linked to shared 
These examples are necessarily anecdotal, even though a close reading of these scholars' works might reveal more facets of what it means to go on fieldwork together. But they do appear to be symptomatic of how anthropology as an institutional and social milieu approaches the fact that there are occasional anthropological couples: while acknowledging that it might be a good idea, anthropological couples create difficulties. ${ }^{12}$ They might want to live together, they might want to work together, they might want to publish together, but this fits badly with how the discipline is organized. For every successful anthropological couple like the Comaroffs, how many others have foundered on the rocks of tenure, professional profile, cooperation and competition, even after managing to do their fieldwork together? How many wives eventually took on a secondary role in terms of textual production (Tedlock 1995)? Was there anything in the specific ways they managed their personal relationships that contributed to their professional success or failure, as the case might be? This concerns questions of strategy, as I have hinted at above, which - while possibly uncomfortable - can hardly be absent when partners negotiate their respective careers and their relationships, especially in a field such as anthropology which puts so much stock in the individual achievements of the researcher under difficult conditions.

Drawing from survey data, Margaret C. Nelson and Deborah L. Crooks, in their study on "Dual Anthropology Career Couples" (where "anthropology" encompasses "archaeology"), found three main barriers to "success for dual-career couples in anthropology" (1994: 63):

“1) lack of mobility, perceived or actual, on the part of one or both members of the couple (this is most often expressed by the woman in our survey); 2) anthropology departments' adherence to anti-nepotism policies that restrict the hiring of both spouses; 3) anthropology departments' slowness in accepting job-sharing as a viable alternative for dual-career couples, as well as a profitable alternative for the departments themselves."

They suspect these barriers to be even stronger for women, and "mobility" seemed to them and their respondents to be the strongest factor overall: "Of the 40

fieldwork or not, Ilva Ariëns and Ruud Strijp make a point of mentioning that an unspecified number from among the 14 couples they had asked for contributions refused to submit anything, citing "recent divorce" as a reason (1989: 6). This is one of the points where discussing partners and spouses of anthropologists feels uncomfortable and intrusive.

12 Consider Matthew Engelke's narrative of how, just as fieldwork, liberated Edith Turner to become an anthropologist herself, the demands of her husband's career had the effect that she played an increasingly smaller role in his writing (Engelke 2001). 
respondents, only 2 did not see mobility as an issue" (Nelson and Crooks 1994: 63). Reading their analysis, the very suggestion of "job-sharing" made me stop short, as I had never considered this as even a possibility; but they go on to cite other studies and cases that indicate that once one partner has managed to get tenure and then effectively entered "demanding negotiation for the hiring of the partner", departments might realize that a happy couple's steady and increased output is an asset that might well off-set costs and other liabilities. ${ }^{13}$

But for several of the examples above (as well as for myself), the question of tenure still lay far in the future when the partners concerned found each other and ventured forth on fieldwork. However, when my partner and I met as graduate students at a very busy international research institute in the field of anthropology, we were very soon exposed to these imaginaries, and - jokingly - confronted with those famous couples who had managed to establish themselves as brands in the discipline. "Oh", some people inquired, apparently both half-mocking and halfcharmed by our apparent commitment to each other as well as to professional anthropology, "will you be working together like [insert a name from the list above]?" This might have been exacerbated by the fact that both of us were mentored by anthropological couples ourselves. But from the beginning, we had the positive experience of people seeing us as each other's peers, with neither considered "senior" nor "junior" (even though I am nearly two years older). This was an impression we actively sought to reinforce over the subsequent years, as we received our $\mathrm{PhDs}$, advanced to new positions, heightened our professional profiles, and eventually came to the agreement to set aside the regions where we had done our respective $\mathrm{PhD}$ fieldwork, and jointly start research projects in a new place, where we expected to be better able to reconcile our fieldwork and our family life.

This last point bears elaboration, as it provided the foundation on which everything else came to rest. What exactly was the process by which we ended up doing fieldwork in Myanmar? Many anthropologists are ready to present anecdotes about how they chose their fields (or how the fields chose them), and often the punchline is that it was simple happenstance or coincidence that led to a (life-) long engagement with a region. Both my partner and I had been absorbed by existing research programs with clear regional foci while we were still in the process of writing our MA theses; we both became established specialists for subregions in East Africa and Central Asia, respectively, and were able to pursue this engagement up until the conclusion of our PhDs. Now, in German anthropology,

13 At this point, Margaret C. Nelson and Deborah L. Crook's paper seems to show its relative age; today, while not entirely unheard of, the suggestion that departments were at liberty to offer tenured positions to partners of faculty staff must be considered stunning exceptions rather than a realistic model. 
there is a mostly unwritten expectation for academic advancement: continuing after the $\mathrm{PhD}$ towards a habilitation requires a thematic and regional shift, a reorientation, ostensibly to prove that one is more than a one-field pony. And although this is at best loosely enforced (and there are prominent exceptions), it is presented as a challenge to junior academics. ${ }^{14} \mathrm{We}$, too, could each have plausibly claimed to have changed field-sites by just crossing a national border or an ethnic boundary, and could have pointed to precedents in which similar maneuvers had been no impediment to further professional success. The benefits of such a limited reorientation are clear - academic networks (which still are largely regionally oriented, as are many positions in the job market) can be maintained, language skills can often be reused or adapted, and regional-cum-historical knowledge might easily carry over into such a "new field". But this seemed hardly feasible; our objectives were, more or less in this order, to be together, to keep doing anthropology, including fieldwork, and to avoid privileging one of us in any way tangibly disadvantageous to the partner. Hence, there could be no shared fieldwork in Central Asia or East Africa - we needed to start afresh, in a place where neither of us had pre-existing academic standing or a head-start in knowledge. Why we specifically picked Myanmar goes beyond the scope of this text; it was sufficiently distant from our previous fields to fulfil our criteria, and it appeared to be a promising site for the future: for many years quite closed to field research, would it not be a strategic move to enter the field now (i.e., subsequent to 2009 when we first discussed these matters) and then be part of the first wave of researchers that surely would materialize "post-opening"? It was also, we agreed after a first touristic visit, a country where we would feel comfortable doing research with a child especially in an urban area.

This shared decision to face together the risk of broadening our established academic profiles - without turning into a conjoined two-headed anthropology chimera in the eyes of our colleagues - and acquiring language skills and regional knowledge as well as building up a new regionalist network together, was decisive for us: it grew into a firm commitment to be partners in our field research as well, with all its unknown vicissitudes.

\section{PRODUCING THE FIELD AND THE PRIVACY OF THE CITY}

Beyond being confronted by their partners' "personalities, qualities, weaknesses and professional objectives", the contributors to the FOCAAL issue Anthropolog-

14 The habilitation in German academia today is losing formal importance, but has not quite lost its aura. 
ical Couples all "struggled to find a way of living acceptable [sic] in the eyes of the native population and satisfactorily for themselves" (Ariëns and Strijp 1989: 18). More intense interpersonal experiences are probably a universal aspect of shared fieldwork time; but this would be true even for camping trips or anything beyond the routine domestic interactions. Rightly highlighted is the additional aspect of the views of "the native population", which shape both expectations beforehand and behavior in the field as well. But the degree and form of this particular aspect can only be guessed at and will certainly show itself in the field in surprising ways. This is also true for the second part: how strongly should one adapt to an observant (and interpreting) public? Will adaptation attempts satisfy local demands? Our fieldwork in Yangon ended up being rather unremarkable in the first respect, and only situationally subject to the second consideration.

I see this as an artefact of urban anthropology, and more specifically, of the conditions in Yangon at the time. During our fieldwork, and even now, it was rather risky in some instances for locals to host foreigners privately for any length of time. In some townships, it was rumored, wardens reported residents just for having overnight guests. Even renting an apartment was so troublesome during our two three-month stays in Yangon in 2013 that we ended up living in a hotel: rent for apartments usually had to be paid up front, for a full year. Later, in 2015, when we had managed to find a place for our family through a broker, we ended up in a section of downtown that had a budding reputation for being foreignerfriendly - "this is your area", a local informant once said, jokingly, but the various sushi places that sprang up there were clear evidence of a gentrification that made some locals rather wealthy. The effect of both the time in the hotel and in the apartment was that we had, without much effort (merely following the typical procedures for people like us in Yangon at the time), achieved a clear separation between "field" and "non-field". More precisely, our residence served as our private retreat, "home" (as per Gupta and Ferguson 1997: 12-13) away from home, in which we slept, worked on our data, played, stored things, cooked, washed our clothes, etc. We had some guests at times, mostly academic colleagues or academically-non-contaminated friends and acquaintances, and some few individuals whom I would classify as "informant-friends", that is, people whom we had initially met through research but with whom we eventually reached a degree of familiarity that we felt comfortable having them in our place. To create this sort of private space (however porous in the end) seemed to us not only practical (and, again, other arrangements would have been rather tricky and unsafe in various ways), but also fair towards our child, who - five days a week - doggedly went to 
attend a private preschool mostly catering for children from upper middle class ethnically Chinese families. His willingness to handle three foreign languages at the same time (Chinese, Burmese, and English), to study "numerics" and to practice choreographies for numerous pop songs at initially barely two years of age, as well as having to deal with the inevitable attention he received as the only European child at this institution, was the only thing that enabled us to do any work in the first place. Thus, we decided that there needed to be a place which was relatively free from outside intrusions, and opted against a nanny to cover the daylight hours when school ended. We were aware that other researchers demanded still more from their children, for example by hiring nannies to enable full eight to twelve hour work days for the parents, but we found our measures adequate in practice. Still, one of us had to drop everything at three pm every day to pick our child up from school; whether more "work" would be possible during those afternoons was often uncertain.

Within our private flat (and the earlier hotel room), there was no such division as we practiced it in our research projects. We also jointly established our contacts with the local university and many of our collegial relations to other researchers who lived in Yangon at the same time. But we soon noticed that we occupied a very particular niche as a researcher couple with a child - most other foreign fieldworkers at the time seemed to be there by themselves, without partner, without child, which of course enabled them to integrate themselves much more intensely, flexibly and with fewer reservations both in the "expat" milieu and in their respective research settings. We must sometimes have felt envious of those who could simply spontaneously change their plans and follow their informants or spend the nights outside in celebration or participation. This way of organizing our daily lives during fieldwork stood in marked contrast to our earlier research in East Africa and Central Asia, where both of us had stayed and worked in rather pheripheral and intimately face-to-face village settings. Our projects in Yangon did not fit with our expectations of how we had learned to do fieldwork before. Methodologically, neither of our research designs required the sort of full immersion we had engaged in previously, and (also due to numerous extraneous commitments) we were simply not as free and untethered as we had been as graduate students. We could accept that.

I want to offer a neologism to characterize the ideal-type "classical" fieldworker, which despite all changes in the discipline (and in the world) still provides a baseline for discussions on how to work and live in the field. Unprepared despite long preparation, one enters the field, one is soon immersed and absorbed by people and the work, and one becomes an anthropologiste totale sociale. This total social anthropologist will not keep up any separation of "field" and "not-field" 
while in "the field": they will be in a place, the place will be the field, they will speak only the local language and interact only with informants, and for them, there shall be only the field until their return to the office. This is clearly a caricature, but I offer the concept as a sensitizing device to instruct our methodological and theoretical reading about fieldwork. For us, it became clear that our approach towards our specific projects in Yangon was adequate. We found it difficult to move beyond the intermediary stage in the national language, Burmese (Myanmar), which was where several language courses and the time in the country had landed us; but it became clear that fully mastering Burmese (while certainly wonderful) would have eventually had diminishing returns: my partner's main informants spoke not Burmese in their private and semi-public interactions, but Farsi or Urdu or Jinghpaw; mine, as professionals in a highly globalized setting, mostly spoke English, and not all of them were citizens of Myanmar in the first place. As Clifford Geertz had it, "the locus of a study is not the object of study" (1973: 22): We did not study a city, we studied in a city; we did not study Myanmar, we studied in Myanmar.

The total social anthropologist as a projection of unrealistic expectations is a challenge to the field researcher. ${ }^{15} \mathrm{I}$ am sure the disconcerting sense of not being in the field quite totally enough has been felt by many. The sense of not being holistically immersed in a lifeworld while feeling that one must be so can be countered: it is not only an unrealistic but sometimes also an unnecessary demand.

Akhil Gupta and James Ferguson's (1997) text on "The Field" as Site, Method, and Location in Anthropology' is helpful here. They suggest that while anthropology and especially the world has changed rapidly ever since fieldwork became part of the brand and disciplinary identity, our understanding of it has remained curiously underdeveloped. One of the alternatives they offer to better address these changes (and to chart a new course for our own approaches) is summed up in the term "location-work" (Gupta and Ferguson 1997: 5), which replaces the "fetishized" commitment to a traditionally understood "field" with an "an attentiveness to social, cultural, and political location and a willingness to work self-consciously at shifting or realigning our own location while building epistemological and political links with other locations" (ibid: 5, 39). This new expression seems to have gained little traction in the discipline at large. But a "good" field-site (or location) is constituted by "its suitability for addressing issues and debates that matter to the discipline" (ibid: 10), rather than an a priori given regional or positional focus. Akhil Gupta and James Ferguson emphasize choice, while acknowledging the role of happenstance and contingency in how people find

15 I do not seek to explore the more sophisticated ways that Marcel Mauss' invocation of the "total social fact" in his The Gift can be read (cf. Valeri 2013). 
their respective fields; they urge acceptance of generative heterodoxies and decenter the tacitly maintained traditional privilege of "the field" as the place away from "home", a dichotomy that continues to generate contradictions, often with a colonialist texture.

This juxtaposition brings me back to the afore-mentioned "informantfriends". ${ }^{16}$ As some local people we had met turned into "friends of the family" whom we enjoyed meeting without any instrumental sense that a meeting had to produce data (even though it often enough did), I eventually realized that they had all come from my partner's side of the research rather than mine. In my estimate, this had less to do with our personalities and general sociability, and more with the way our respective fields were constructed. My partner's research focused on urban religious minorities, Hindus, Muslims, Christians, who all pursue different strategies, both individually and as "religious communities", to maneuver their lives and practices within predominantly and sometimes rather insistently Buddhism-focused Myanmar. Throughout fieldwork, all three of us became familiar faces especially around some Mosques, and our child and I often joined Church celebrations, Hindu processions or Muslim feasts. That we had come to Yangon as a family was perceived and appreciated; it might even have helped my partner's access to some milieus or individuals, but that must remain speculative. My critical research on the politics of cultural heritage, on the other hand, drew on observation at public events and places (with a degree of participation), interviews, and other situated methods. While I also got to know some individuals quite well and became a familiar face at "heritage events" myself, there was never a stable presence of people in a place, no multiplex "community", only fluctuating networks and semi-stable assemblages that soon dispersed. My informants, the people I got to know better, were experts in a general sense, journalists both local and foreign, artists, gallerists, activists, architects, officials. My access to them largely depended on my ability to ask interesting questions, and - in a crass contrast to my partner's situation - not at all on my potential social roles as father or husband. In the terms suggested by Julia Pauli (this volume), my partner encountered (and satisfied) "family normativity", and I did not - nobody among my informants cared much about who I was beyond being a person who asked them questions. Sometimes it is said of anthropologists that "family is something that the Other has"; in my case, I experienced the exact opposite, to my occasional consternation.

16 The term "informants" is considered problematic by some. I still use it, as suggested alternatives such as respondents, collaborators, consultants, participants, or research subjects come with their own sets of problematic associations. The construction of "informant-friends" hints at the difficulties of positionality. 
My partner's informants became informants qua their belonging to stable groups that met at and often resided near religious buildings and belonged to selfidentifying "communities", along with their families and neighbors in classical multiplex relationships. My informants mattered to my project as individuals who through their personal qualifications had achieved expert status and come to be involved in certain projects. Leaving aside some complexities, I can contrast our fields: there, people were active in communitarian projects; here, my informants were involved in networking. This analogy simplifies matters, but it explains why virtually no "informant-friends" came from "my side" - my interlocutors kept their families and other social entanglements outside of their involvement in "heritage", i.e., the professional arena where I met them. Bringing my child along to certain events had no tangible effects in that it made anyone want to get to know us on a more than professional, object-oriented level. Considering the spectacle that our child occasionally caused in public in Yangon, where I carried him everywhere in a child carrier backpack, this is saying something about the contexts in which I moved.

Figure 9: Making our way through a street fair (Bo Yar Nyunt Lan, Yangon, 2016).

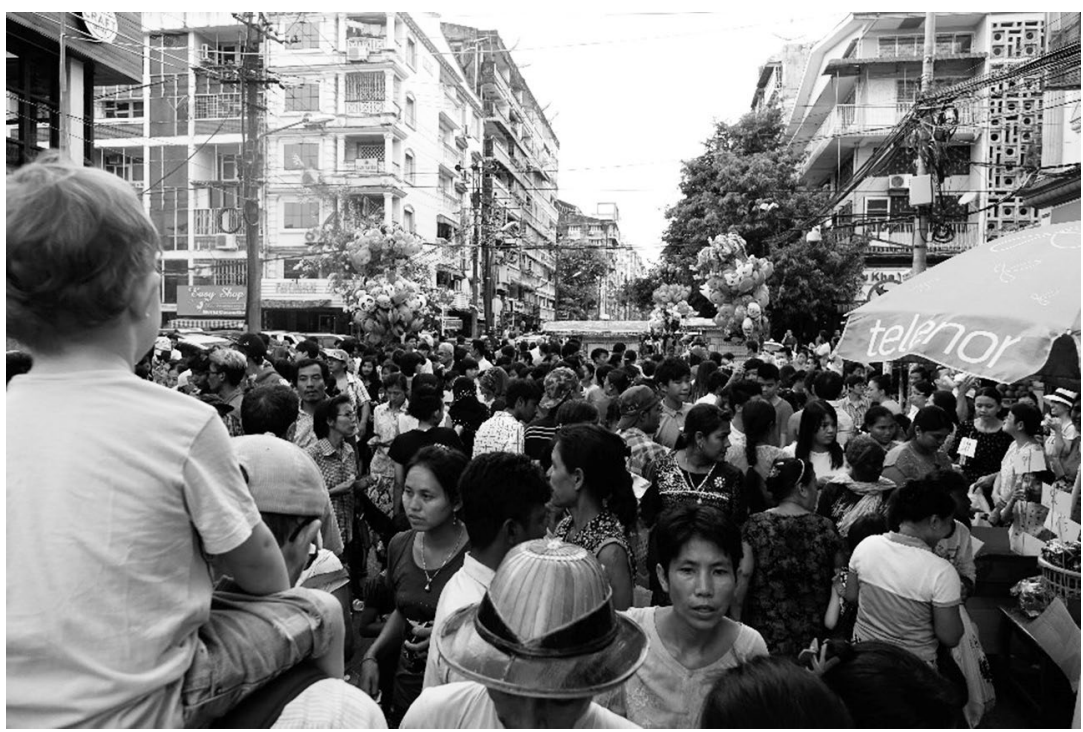

(C) Judith Beyer

In an everyday sense, my partner and I were in the field in one location, together with our child - sharing it; in a methodological sense, we were in two fields - or a divided field. One field was community-oriented in terms of methods, as there 
were stable assemblies of people and places. The other was network-oriented and consisted mainly of experts who had little motive to turn their personal backgrounds into aspects of their professional lives; but I was, in effect, researching their professional activities. This was a division of fields that we had not expected, even though we probably could have.

\section{CONCLUSION}

Thinking through the issues of two professional anthropologists who decide jointly to venture out on fieldwork in the same geographical location while deciding that their professional profiles must be kept apart - unlike those of many of the "anthropological couples" who have come before us - has given me a new appreciation of, mostly, the choices we made in constructing not only our fields but also our life in the field. Some of these choices were debated beforehand, while on others (so it seems to me in retrospect), we tacitly agreed upon. Despite these choices, it took me a while to articulate the most marked contrasts between our research situations: to state that we were in two different fields is no exaggeration - unlike some of those anthropological couples mentioned above, who were not only in the same place but seemingly worked together on the same things at times. This brings out how only the nexus of research design, methodology and social assemblages in a location truly makes a field. The decision to draw a line between "the field" (outside) and "home" (where we still worked, but also intentionally did not maximize our work at the expense of the family and partnership) was palatable for both of us as we had the secure knowledge that we had already previously "done" fieldwork as "total social anthropologists" as graduate students (in the vein of Georg Marcus' "first fieldwork" [2009: 9]). To emulate again the ways we had studied in our respective villages was neither necessary nor particularly better. That we kept our research projects separate and then ended up having wholly different social positionalities vis-à-vis our informants was an unintended parallelism; another unexpected outcome was that our radical egalitarianism in how we divided our domestic duties in the field had the effect that our child for a long while after fieldwork used our established terms of address interchangeably. Apparently, it mattered little who was "Mama" and who was "Papa". At the same time, I suspect that the way we divided domestic duties in the field still shapes the way we organize our family today, long after those formative months the three of us spent in Yangon. While I cannot in good conscience advocate the way we did fieldwork in Myanmar as a model for other anthropological couples to emulate, as we were rather privileged in terms of funding and employment throughout, I do 
consider this symmetrical approach an appropriate adaptation over older models and practices. Keeping our profiles separate is occasionally bothersome; but we expect that it would be unwise to - for example - write a joint monograph where our respective contributions (especially as they relate to fieldwork) are not carefully kept apart before both of us have tenure, as some other anthropological couples have previously done.

It could certainly be argued that this paper might have profited if my partner and I had written it together; but the sense that we share, that conflation of two distinct academic careers, research fields and even names is a real and tangible risk to professional success today (maybe even more so than in the past), seemed to be better illustrated by offering a single-author paper to this volume. ${ }^{17}$ Note that the divided positionality we pursue is largely based on expectations rather than on actual feedback or on any negative experience of having been treated as one conjoined unit rather than as two professional individuals: but such is the influence of institutional history and the precarious job market that it directly impacts on the fraught nexus of family and fieldwork.

\section{REFERENCES}

Appelbaum, Kalman (2011): "Jean and John Comaroff. Film Interviews with Leading Thinkers." Available online at http://www.alanmacfarlane.com/DO/ filmshow/comaroff_fast.htm (last accessed September 16, 2019).

Ariëns, Ilva/Strijp, Ruud (1989): “Anthropological Couples. In the field and beyond.” In: Focaal 10, pp. 5-24.

Ben-Ari, Eyal (1987): “On Acknowledgements in Ethnographies.” In: Journal of Anthropological Research 43/1, pp. 63-84.

Butcher, Jim (2003): The moralization of tourism. Sun, sand ... and saving the world?, London and New York: Routledge.

Butler, Barbara/Turner, Diane Michalski (1987): Children and anthropological research, New York: Plenum.

Cassell, Joan (1987): Children in the field. Anthropological experiences, Philadelphia: Temple University Press.

Cornet, Candice/Blumenfield, Tami (2016): Doing fieldwork in China...with kids! The dynamics of accompanied fieldwork in the People's Republic, Copenhagen: NIAS Press.

17 I do not even thank my family in a footnote. 
Engelke, Matthew (2001): "Books Can Be Deceiving. Edith Turner and the Problem of Categories in Anthropology." In: Anthropology and Humanism 26/2, pp. 124-133.

Geertz, Clifford (1973): The Interpretation of Cultures. Selected Essays, New York: Basic Books.

Gupta, Akhil/Ferguson, James (1997): "Discipline and Practice. 'The Field' as Site, Method, and Location in Anthropology." In: Akhil Gupta/James Ferguson (eds.), Anthropological Locations. Boundaries and Grounds of a Field Science, Berkeley: University of California Press, pp. 1-46.

Halme-Tuomisaari, Miia (2017): "Yes we can - and this is how! \#fieldwork with kids." In: Allegra Lab. Available online at http://allegralaboratory.net/yes-wecan-and-this-is-how-fieldwork/ (last accessed September 16, 2019).

Hart, Keith (2015): “Jack Goody (1919-2015). An oral history.” Available online at https://savageminds.org/2015/09/15/jack-goody-1919-2015-an-oral-history/ (last accessed September 16, 2019).

Heybrock, Mathias (2018): „Besser nicht allein ins Feld. Transkulturelle Teams in der Ethnologie bereiten Studierende auf Kooperation in der Arbeitswelt vor.“ In: Uniwissen 01/2018, pp. 40-43. Available online at http://www.pr. uni-freiburg.de/publikationen/uniwissen/uniwissen12018.pdf (last accessed September 16, 2019).

King, Lily (2014): Euphoria, New York: Grove.

MacFarlane, Alan (2007): "Interview with Stephen Hugh-Jones. Film Interviews with Leading Thinkers." Available online at https://www.sms.cam.ac.uk/media/1122016 (last accessed September 16, 2019).

Marcus, George (2009): "Notes towards and ethnographic memoir of supervising graduate research through anthropology's decades of transformation." In: James D. Faubion/George Marcus (eds.), Fieldwork is not what it used to be. Learning anthropology's method in a time of transition Ithaca, New Jersey: Cornell University Press, pp. 1-34.

McGranahan, Carole (2015): "Yes, you can. Being an academic and a mother redux." In: Allegra Lab. Available online at http://allegralaboratory.net/yesyou-can-being-an-academic-and-a-mother/ (last accessed September 16, 2019).

Nelson, Margaret C./Crooks, Deborah L. (1994): "Dual anthropology career couples. Different strategies and different success rates.” In: Archeological Papers of the American Anthropological Association 5/1, pp. 59-64.

Schlehe, Judith (2013): "Wechselseitige Übersetzungen. Methodologische Neuerungen in transkulturellen Forschungskooperationen." In: Thomas 
Bierschenk/Matthias Krings/Carola Lentz (eds.), Ethnologie im 21. Jahrhundert, Berlin: Reimer, pp. 97-110.

Strathern, Marilyn (2009): "Marilyn Strathern, interviewed by Alan Macfarlane May 6, 2009." Available online at https:/www.haujournal.org/haunet/ strathern.php (last accessed September 16, 2019).

Strathern, Marilyn/Czegedly, Andre P. (1992-93): “(Re-)Production of the Self. An Interview with Marilyn Strathern.” In: The Cambridge Journal of Anthropology 16/3, pp. 1-18.

Strecker, Ivo/Lydall, Jean (1979): Work Journal, Hohenschäftlarn: Renner.

Strecker, Rosie/Strecker, Ivo (1995): "Sweet Sorghum.” 32 min, Watertown, Massachusetts: DER.

Tedlock, Barbara (1995): "Works and Wives. On the Sexual Division of Textual Labor." In: Ruth Behar/Deborah Gordon (eds.), Women Writing Culture, Berkeley: University of California Press, pp. 267-286.

Thomas, Martin/Harris, Amanda (2018): Expeditionary Anthropology. Teamwork, travel and the 'science of man', Oxford and New York: Berghahn.

Toivanen, Reetta (2015): "Redux. \#fieldwork with children." In: Allegra Lab. Available online at http://allegralaboratory.net/fieldwork-with-children/ (last accessed September 16, 2019).

Valentin, Andrea (2009): The role of political awareness in backpacker decisionmaking: University of Otago, Dunedin, New Zealand, $\mathrm{PhD}$ thesis.

Valeri, Valerio (2013): "Marcel Mauss and the new anthropology." In: HAU: Journal of Ethnographic Theory 3/1, pp. 262-286. 